\title{
Analytical Review of the Australian Policy Context for Work-Related Psychological Health and Psychosocial Risks
}

\author{
Ms. Rachael Potter (corresponding author) \\ Asia Pacific Centre for Work Health and Safety \\ School of Psychology, Social Work and Social Policy, the University of South Australia \\ A2-22, Level 2, A Building, Magill Campus \\ Adelaide, South Australia 5072 \\ Email: rachael.potter@mymail.unisa.edu.au \\ Telephone number: +610435329680 \\ Dr Valerie O'Keeffe \\ Asia Pacific Centre for Work Health and Safety \\ School of Psychology, Social Work and Social Policy, the University of South Australia \\ A2-22, Level 2, A Building, Magill Campus \\ Adelaide, South Australia 5072 \\ Australia
}

Email: Valerie.O'Keeffe@unisa.edu.au

Professor Stavroula Leka

Faculty of Medicine \& Health Sciences, the University of Nottingham

Room B02 Yang Fujia Building

Jubilee Campus

Wollaton Road

Nottingham

NG8 1BB

UK

Email: Stavroula.Leka@nottingham.ac.uk

\section{Professor Maureen Dollard}

Asia Pacific Centre for Work Health and Safety, Faculty of Medicine \& Health Sciences at University of Nottingham

School of Psychology, Social Work and Social Policy, the University of South Australia A2-22, Level 2, A Building, Magill Campus

Adelaide, South Australia 5072

Australia

Email: Maureen.dollard@unisa.edu.au

\section{Ms. Mardi Webber}

Consultant, Mentally Healthy Workplaces

Underwriting \& Risk Management

400 King William Street

Adelaide, South Australia 5000 
Email: mardi.webber@rtwsa.com

\section{Declaration of Interest}

Declarations of interest: none.

\section{Acknowledgement}

Rachael Potter would like to acknowledge the Commonwealth Government funding that she received under the Research Training Program while undertaking a PhD. 


\begin{abstract}
Psychosocial hazards and risks are widely acknowledged to be a serious challenge in WHS. WHS regulatory (hard law) and non-regulatory binding (soft law) policies should strive to engage organisations in psychosocial risk management practices and set a standard for good psychological health in the workplace. Therefore, policies should contain key definitions and aspects of good-practice psychosocial risk management principles. However, at present there has been limited review on policy in this area, despite growing evidence of poor work-related psychological health. Using qualitative methods, the current paper reviews relevant regulatory and non-regulatory policy documents and conducts a gap analysis according to criteria identified in models of good psychosocial risk management practice. The paper extends upon European research by Leka et al. (2015) and examines 39 policies (6 regulatory and 33 non-regulatory) in Australia. We found that most policy documents included psychological health in the objective of the policy. Moreover, non-regulatory policies showed sound coverage of exposure factors and preventive actions and, to a slightly lesser degree, risk assessment. Non-regulatory policy documents scored higher than regulatory policies. Within regulatory policies, there is poor inclusion of risk assessment, preventive action and poor coverage of exposure factors and psychological health outcomes. All policies could be strengthened by including greater coverage of work-related psychological health problems/disorders and associated outcomes. This is a novel review, which contributes to a broader program of research on Australian WHS policy. The next research phase seeks detailed information from WHS experts about the effectiveness and/or implementation of these policies in order to ascertain potential improvements.
\end{abstract}




\section{Introduction}

There is growing community and research awareness on the influence of psychological and social aspects of the work environment, which extend beyond more traditional or technical work factors (Sadlowska-Wrzesińksa, 2014). Specifically, researchers have identified that work-related psychosocial hazards are highly related to new challenges of work, and contribute to a range of adverse individual, organisational and societal outcomes (Health and Safety Professionals Alliance [HaSPA], 2012). Occupational psychosocial hazards are defined as aspects of work design, organisation and management, which arise from the social and organisational environment, and that have the potential to cause harm (Cox \& Griffiths, 1996). Psychosocial risk is conceptualised as the likelihood and consequence of that harm occurring (Cox \& Griffiths, 1996). Examples of psychosocial hazards include excessive workloads, high emotional demands, low autonomy and role conflict (Bluff, 2016). Since psychosocial hazards also refer to interpersonal relations, they comprise low levels of co-worker support, lack of managerial recognition, instances of bullying and harassment, and occupational violence (Bluff, 2016). Psychosocial hazards are multifaceted and more complex than physical hazards in the workplace (Cox, Griffiths, \& Rial-Gonzalez, 2000; Jespersen et al., 2016), and are negatively associated with employees' physical health (Bailey, Dollard, McLinton, \& Richards, 2015; Li, Dollard, Loerbroks, \& Angerer, 2015) and psychological health (EU-OSHA, 2017; Hall et al., 2010). Psychological health (a term used interchangeably with mental health) is defined by the World Health Organization (WHO, 2018) "as a state of well-being in which every individual realises their own potential, can cope with the normal stresses of life, can work productively and fruitfully, and is able to make a contribution to her or his community".

National WHS policies are instruments that shape societal action around the protection of both physical and psychological health and safety matters. In fact, a nations' or regions' WHS regulatory policy framework ascertains the rights and obligations of particular 
individuals and authorities, and inevitably generates the broader context in which organisations operate (Leka \& Jain, 2014). Policy consists of both legally binding instruments (national pieces of legislation) and other "hard" polices developed by recognised national and international organisations, and international organisations, as well as nonbinding/voluntary policies (or "soft" policies) which may take the form of recommendations, resolutions, opinions, proposals, conclusions of institutions (Commission, Council, and Parliament), social partner agreements and frameworks of actions, and specifications, guidance, campaigns, and so forth, instigated by recognised national and international committees, agencies, and organisations. However, research into the review and analysis of such WHS policy instruments has been overlooked, particularly in the area of work-related psychological health. As a result, this study aims to provide a resource that identifies and evaluates all Australian WHS regulatory and non-regulatory policy instruments, at the national and regional-level, relevant to work-related psychological health and psychosocial risk management. Using descriptive and qualitative methods, the objective of this paper is to convey the current position and strengths of the Australian WHS policy framework in the area of psychological health, as well as to prompt investigation into areas that require further action and development.

\section{The Prevalence and Impact of Work-Related Psychosocial Hazards on Psychological}

\section{Health in Australia}

In Australia, national surveillance of psychosocial hazards and health outcomes (see Dollard \& Bailey, 2014; Dollard et al., 2012) highlights several concerns regarding psychosocial hazards and psychological health. For instance, more than $40 \%$ of participants $(n=5743)$ in the AWB project (see Dollard \& Bailey, 2014) reported excessive working hours, working over the national standard of 38 hours, and 18\% were working longer than 48 hours a week (Dollard et al., 2012). Also, workplace bullying is of great concern, with increased prevalence rates across 
the country, rising from $6.1 \%$ in 2012 to $9.7 \%$ in 2014/15 (Potter, Dollard, \& Tuckey, 2015). In addition, a national study comprising 1,126 interviews (beyondblue, 2014) found that one in five Australians $(21 \%)$ have taken time off from their work within the last year because they felt stressed, anxious, depressed or psychologically unhealthy. This rate more than doubled to $46 \%$ for those employees who felt that their workplace was psychologically unhealthy. Furthermore, only five in ten $(56 \%)$ participants felt that their senior leader valued their psychological health (beyondblue, 2014).

Work-related psychosocial hazards and poor psychological health have widespread economic impacts on Australia. In particular, psychological injury claims are steadily increasing over the last decade and account for the highest average cost of all workers' compensation claims (SWA, 2013). Each year 7,820 Australian workers are compensated for work-related mental disorders, costing on average $\$ 23,600$ per claim and involving an average of 15 weeks off work (SWA, 2015). Since 2006, the cost of these compensation claims has doubled and is now estimated at AUD \$543 million annually (SWA, 2018). Significantly, these claims may actually underestimate the incidence of injury and illness that arise from psychosocial hazards at work. Estimates suggest that only two thirds of employees who encounter psychological stress are entitled to, or request workers' compensation (ABS, 2010). In addition, developments in workers' compensation legislation now make it more difficult to receive compensation for both physical and psychological injury (SWA, 2015).

Work-related anxiety and depression are estimated to cost businesses in Australia \$10.9 billion annually, consisting of $\$ 4.7$ billion in absenteeism, $\$ 6.1$ billion in presenteeism and \$146 million in compensation claims ( $\mathrm{PwC}, 2014)$. Additional research purports that depression in particular costs Australian employees around $\$ 8$ billion per annum because of sickness absence and presenteeism (McTernan, Dollard, \& LaMontagne 2013). However, of this amount, $\$ 693$ million per year is attributable to job strain and bullying, which are 
psychosocial hazards that can be managed by workplaces (McTernan et al., 2013).

Furthermore, national surveillance data suggests that having poor workplace PSC costs employers around AUD 6 billion per annum (Becher \& Dollard, 2016), and if the psychological wellbeing of the $25 \%$ least psychologically healthy was raised then this could save AUD 17 billion (McTernan, Dollard, LaMontagne, 2014). From a moral and economic standpoint, Australian working conditions must be improved to minimise the personal and financial consequences on individuals and society.

Academics and expert practitioners agree that future efforts to address work-related psychological health must be broadened to consider the full range of working conditions that contribute to poor health (Leka, Jain, Iavicoli, \& Di Tecco, 2015). Such an approach should encompass a proactive focus, tackling problems at the source, rather than purely reacting to the emergence of diagnosed psychological injuries. A preventive approach is theoretically supported by the innovative PSC work stress theory (see Zadow \& Dollard, 2015 for review), which asserts that targeting upstream organisational factors is more effective than individual work design or outcome factors. Therefore, instead of concentrating on isolated issues or outcomes (e.g., depression), a greater effort must be invested in implementing expansive policies and practices that target the leading risk factors in the preceding work conditions. These policies should encompass core psychosocial risk management principles in order to most effectively identify, eliminate or minimise risk to health. In essence, it is imperative to consider how work-related psychological health is approached from a broad national or policylevel perspective, because a robust regulatory policy framework is fundamental in the protection of health (EU-OSHA, 2012; Leka, Jain, Zwetsloot, Vartia, \& Pahkin, 2008). First, WHS regulation has a vital role in driving organisations to perform specific obligations relevant to protecting employee health. Second, WHS regulation also offers a framework for WHS regulators to monitor organisational compliance with the law, as well as providing a basis 
for the enforcement of improvements (Johnstone, Quinlan, \& McNamara, 2011). Large-scale or national policies communicate a national standard, and convey the level of importance, that employers should place on the psychological health of their employees. However, at present there is limited review or analysis on the role of policy in this context.

Australia's' Policy on Work-Related Psychological Heath and Psychosocial Risk

\section{Management}

Within Australia, each region (i.e. state or territory) has jurisdiction over WHS legislation. Each jurisdiction has legally binding regulatory instruments that stipulate the broad legal obligations to protect the health and safety of employees at work. Specifically, the Commonwealth and jurisdictions' WHS Acts and Regulations are the top policy layers that outline the responsibility to address psychosocial hazards via duties and obligations that cover both psychological and physical health (see Figure 1). Then, there are softer policies that provide a more detailed focus on work-related hazards and outcomes. For instance, psychosocial hazards are mentioned within a Managing Work Health and Safety Risks Code of Practice. Guidance material is also available, particularly in Western Australia and Victoria, to address specific psychosocial hazards such as occupational violence.

In 2011, efforts were taken to reform and standardise the WHS regulatory framework across Australia, through the release of a model WHS policy package for jurisdictions to adopt via their own parliamentary processes. The process of standardising the WHS policy approaches across Australia is referred to as harmonisation, and was intended to reduce major differences between the jurisdictions regarding terminology, standards and penalties for noncompliance with WHS law. A major development of the policy harmonisation was the introduction of a more inclusive definition of health as both physical and psychological in the WHS Model Act. Most jurisdictions agreed to adopt the new policy framework (for details see 
Johnstone, 2008), yet enactment of the Model WHS laws occurred at slightly different times across participating jurisdictions. However, Western Australia and Victoria retained their own legislation and did not participate in harmonisation. Western Australia's legislation does not include any reference to psychological health or psychosocial issues. Victoria's legislation is similar to the model legislation and does specify that risks to psychological health should be managed. Regardless of the specific legislation, within all Australia jurisdictions, organisations have a duty of care to ensure safe and healthy workplaces for their employees.

Each jurisdiction has capacity to implement its own WHS laws under the Constitution, so the model laws have been adopted with minor variations to suit local conditions. However, other challenges exist around the implementation and maintenance of harmonised regulatory regimes. Bluff and Gunningham (2012) highlight numerous inconsistencies between harmonised regions, such as differences in structures and resources, as well as differing state priorities and targets that all impact policy implementation. Yet, there is little to no systematic identification of implications associated with policy change in Australia, especially in the context of work-related psychological health. To date, one study by Potter et al. (2017) has assessed the change in the WHS policy in relation to psychological health over two time points, using an evidence-based indicator called PSC (see Dollard, 2012). The findings show support for harmonisation, as Western Australia (un-harmonised) reflected a decline in reported PSC levels over time.

Outside the regulatory WHS policy framework, there also exists legally binding provisions through industrial laws to protect workers psychological health and safety. For instance, the Commonwealth Fair Work Act (2009) deals with matters of workplace bullying and permits an employee to apply to the Fair Work Commission for an order to stop bullying at work. In one jurisdiction (Victoria), there are stalking provisions in the Crimes Act (1958) that extend to behaviours that involve serious bullying. Although, WHS regulatory agencies remain 
the main authority for ensuring organisations' obligation to provide a safe workplace (HaSPA, 2012). The WHS (or occupational health and safety, OHS) regulators are the chief actors in setting and monitoring work standards and strive to ensure that workplaces provide fair and effective representation, consultation, cooperation and issue resolution. Other critical parties in ensuring good WHS standards are union delegates and leaders, who participate in policy decision-making processes. Further, elected Health and Safety Representatives have prescribed powers under the WHS laws to protect and promote health and safety at work.

Throughout the last five years, the broader Australian WHS policy context has seen a push in awareness and prioritisation of psychological health at work. Major drivers have been the extreme costs, time and complexities associated with psychological injury compensation claims. Therefore, psychological health is now one of the main targets of the national Australian Work Health and Safety Strategy 2012 - 2022 (SWA, 2012b). Furthermore, not-forprofit organisations and community groups have taken the lead in promoting psychological health at work through offering educational workshops and resources, including web-based information and tools (see Heads Up, 2017).

\section{The WHS Policy Framework and Psychological Health}

The accountability for managing WHS is outlined within a WHS (or occupational health and safety $[\mathrm{OHS}]$ ) regulatory framework, encompassing four levels of policy (Acts, Regulations, codes of practice and guidance material; Stewart, 2013). As the highest level in the regulatory policy framework, the WHS Act establishes broad duties and obligations for employers and other persons conducting businesses or undertakings to ensure workers' health and safety (so far as reasonably practicable) (SWA, 2012b; Stewart, 2013). In most jurisdictions, psychological health is included in the definitions within the Act. The duties do not specifically describe psychosocial hazards; rather they are structured in broader terms, relating to the work 
environment or systems of work. Employers must provide safe systems of work, health monitoring, consulting and information, training, instruction and supervisor. There is also a duty of due diligence, which requires employers to take reasonable steps to acquire and update knowledge about WHS matters such as psychosocial hazards and risks.

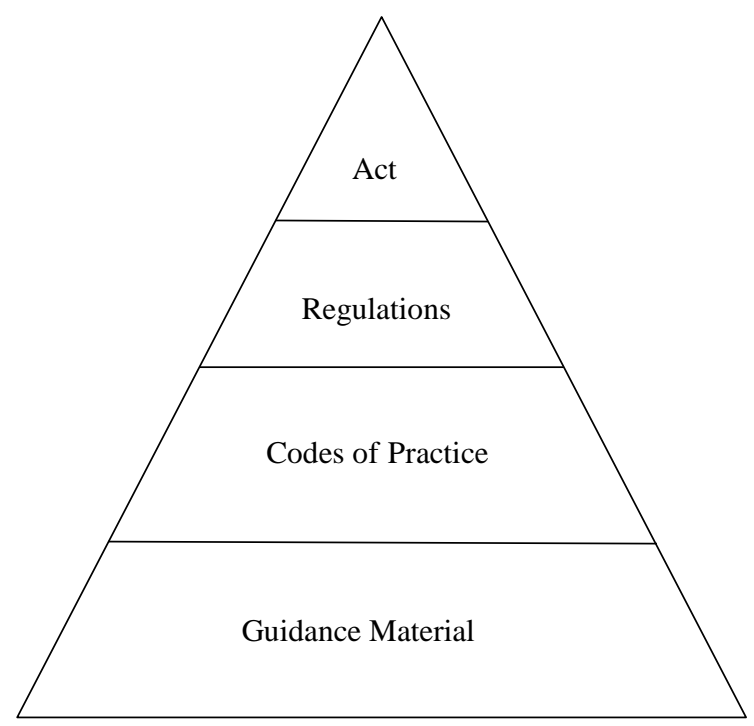

Figure 1 Pyramid of WHS policy layers.

The WHS Act is supported by WHS Regulations, which are legally enforceable directions for how a duty holder must discharge their duty of care in relation to specific highrisk hazards at work (Stewart, 2013). Regulations mandate standards of risk controls and employers are required to put in place risk control measures to ensure that risks arising from known hazards are properly controlled. However, both the harmonised and non-harmonised Regulations make no reference to the terms 'psychological', 'psychosocial hazard ', 'psychosocial risk' or 'work stress'. Within the literature, no reasons have been provided to justify the omission of related terms in the policies. Comparable to other countries (Lippel, Vézina, \& Cox, 2011), Australian WHS inspectors rely on broad obligations in the legislation to regulate psychosocial risks in workplaces (Johnstone et al., 2011; Weissbrodt \& Giauquie, 
2017). In response, most regulators are developing a greater inspectorate capability in addressing psychosocial hazards, primarily through appointing groups of specialised psychosocial inspectors, who have specific training in assessing and managing the presence of psychosocial hazards in targeted groups (Bluff, 2016; Johnstone et al., 2011).

Regulatory policy instruments are supported by non-regulatory policy instruments; specifically Codes of Practice and guidance material (see Figure 1). Codes of Practice are not legally binding yet may be admissible in court, and provide a higher level of detail on the practical actions that should be taken to ensure compliance. In relation to psychological health, in jurisdictions with the harmonised WHS legislation, there is an approved Code of Practice for the management of risks in general, with examples of work-related stress, bullying, violence and fatigue included to describe types of psychosocial risk management (SWA, 2010). Following the Codes of Practice, guidance material further assists with the translation of the legislated obligation into practice. Within all jurisdictions guidance material helps illustrate specific examples of practice for managing issues such as bullying and harassment, fatigue and occupational violence.

\section{Evidence on the Role of the Australian WHS Regulatory Policy Framework \& Psychological}

\section{Health}

There is limited research that highlights the impact that policy frameworks have on the regulation of psychosocial risks in Australia (see Quinlan, 2007, Quinlan, McNamara, \& Johnstone, 2009: Johnstone et al., 2011). Between 2003 and 2007, Johnstone et al. (2011) undertook 120 workplace observations and interviews with 36 inspectorate managers and 89 inspectors to understand how inspectors respond to psychosocial hazards, with respect to the legislation at the time. The findings showed that the general duty provisions of the legislation included psychosocial hazards, however much of this focus was on bullying, harassment and 
stress. As such, other important psychosocial hazards were likely to be overlooked. Importantly, the results highlight particular concerns around the resolution of psychological claims (i.e. bullying) due to greater complexities, the need for more resources, and inspectors generally reporting greater difficulty in resolving psychosocial issues compared to physical issues (e.g., manual handling). Further, the study established that inspectors struggled in enforcing prosecution of psychosocial issues, and argued that the law is inadequate in this area. In particular, the participating inspectors emphasised a lack of clarity of the provisions in the law, which reduced their level of confidence in enforcing much needed action within workplaces. Yet this study (in addition to Quinlan, 2007 and Quinlan et al., 2009) occurred prior to the policy harmonisation process in 2012.

Recently, the PSC framework and tool (Dollard, 2012) has been used to evaluate the impact of policy harmonisation across Australian jurisdictions at the organisational-level (Potter et al., 2017). The results showed support for the national policy standardisation process; as jurisdictions that adopted the legislation that specified psychological health reflected increased participation and consultation on employee psychological matters. Whereas, the jurisdiction with legislation that did not include psychological health showed a decrease in management commitment, priority and communication in relation to psychological health over time. Findings emphasise the need for further Australian research on policy implementation, particularly through acquiring WHS regulator perspectives on the issue.

In addition, several authors have argued that work-related psychosocial hazards are not sufficiently address in Australian WHS legislation (OECD, 2015; Bluff, 2016). Bluff (2016) conducted an international comparative analysis of regulation and governance of work-related psychosocial risk management. In an overview of the Australian regulatory approach, Bluff's (2016, p.140) commentary aligns with the findings by Johnstone and Quinlan (2008), making reference to the fact that in Australia "a key issue is determining how to apply the general 
obligations in the laws for health and safety at work to psychosocial risks, in the absence of specific regulations". Such findings - coupled with increasing psychological injury claims question the current adequacy of WHS policy approaches and the level of protection of employee psychological health. The debate is further fuelled by outcomes of research studies. For instance, in Australia, whilst $76 \%$ of people view their workplace as physically safe, only $52 \%$ perceive their workplace as being mentally healthy (beyondblue, 2014).

Despite the widely-acknowledged importance of WHS regulatory frameworks, and the prevalence of poor work psychological health, psychosocial risk management has been particularly overlooked within the Australian research policy literature. While there have been various studies exploring the broader role of WHS polices, inspection and regulation - there has been limited examination of the context of psychological health or psychosocial risk management. Instead, these studies focus on aspects such as the function of the particular policy (e.g., the roles of codes and guidance material and other instruments in Gunningham \& Bluff, 2009; Gunningham \& Bluff, 2008), inspection in relation to broader or industrial relation matters (e.g. contingent work) (Quinlan, Johnstone, \& McNamara, 2009), the role of inspectors, regulation and enforcement more generally (Bluff, Johnstone, McNamara, \& Quinlan, 2012; Schofield, Reeve, \& McCallum, 2014), and the harmonisation process (Bluff \& Gunningham, 2012). Australian WHS policy research lags greatly behind the European literature, in which there have been numerous studies (see Leka, Jain, Iavicoli, Vartia, \& Ertel, 2011; Leka et al., 2015 for examples). This research discrepancy is of great concern, particularly since it is purported that through the points of prevention, European legislation is more extensive than Australian legislation with respect to psychosocial risk management (Bluff, 2016). Considering the prevalence of psychological injury rates and poor work-related health in Australia, the investigation of WHS policy approaches can no longer be ignored. There is a clear need to understand the current policy position on this matter, through reviewing 
the available policy documents and subsequently deciphering areas of strength in addition to points for further improvement.

\section{Method}

The study adopts a methodology conducted by Leka et al. (2015), based on a policy scorecard approach. The first step in the process was to identify all hard and soft law policies relevant to work-related psychological health and psychosocial hazards. Regulatory documents refer to Acts and Regulations, and non-regulatory policies specifically refer to Codes of Practice, guidance material and psychosocial risk management tools. We identified policy instruments through two processes. First, the researchers conducted their own review of all jurisdictions' available policy documents. Second, WHS regulators from South Australia and New South Wales (both harmonised); and Victoria and Western Australia (both non-harmonised) assisted in identifying relevant material. The expert informants (participants) were contacted via email in early to mid-2017 and were known to the researchers (via conferences and previous work experience) as being highly informed in the area of WHS policy and psychological health regulation. Each respondent completed a template and were able to enlist the help of other experts within their jurisdiction.

The second step involved a gap analysis to investigate the degree to which the Australian policy framework covers issues relevant to psychological health at work. The gap analysis referred to a set of defined criteria in the form of a policy scorecard (see Table 1). Each policy instrument was scored on a scale of "0-5" in line with its relevance/applicability and/or coverage of five criteria relating to psychological health at work. The five criteria were selected as representative of good practice guidance (WHO, 2008) and include reference to psychological health to in the objectives and scope of the policy, coverage of exposure factors, psychological health problems/disorders at work and related outcomes, risk assessment aspects, 
and preventive actions in relation to psychological health in the workplace. Policy documents that did not state or cover psychological health at work were scored 0 , whilst policies that were highly relevant and comprehensive in their coverage of the aspect were scored 5.

Each policy document was reviewed by three researchers to examine the policy content and assign scores based on the criteria. To ensure inter-rater reliability, first, researchers conducted an independent scoring of the policies. Second, the researchers convened at three separate meetings to triangulate the policy scores. Third, if there were any discrepant policy scores on any criterion, agreement was achieved through collaborative reanalysis and discussion to achieve a total or majority consensus. All researchers have strong academic experience in the area of the regulation of psychological health in Australian workplaces. Two of the researchers have extensive experience in Australian WHS as practitioners and academics, and have employment backgrounds involving the regulation of psychological health and psychosocial risk management. The other researcher is nearing completion of a $\mathrm{PhD}$ in WHS (and has conducted previous research and publications) with a central focus on policy-level approaches and work-related psychological health.

\section{Results}

The review identified 39 documents. Table 2 presents the ratings of the Acts and Regulations. Three Acts and three Regulations were identified. Table 3 shows the scores for the seven relevant Codes of Practice policy documents identified. Table 4 presents the scores for 26 guidance material. Twenty six guidance documents were identified relating to psychological health or psychosocial hazards. There was variation in the scoring for the Acts and Regulations based on whether the jurisdiction was harmonised or not. The WHS Act 2011 (harmonised) and Victoria's Act all scored higher than Western Australia's Act and Regulations. Overall, most of these regulatory documents scored poorly across all criteria. The Codes of Practice scored 
higher overall in comparison to the Acts and Regulations. The guidance material documents scored highest overall, compared to the Acts and Regulations and the Codes of Practice.

In line with previous methodology by Leka et al. (2015), the policy documents that had overall scores of twenty are regarded as having sufficient coverage of the psychosocial risk management principles needed to achieve good work-related psychological health. Eleven policy documents were identified as meeting or exceeding this score. Average scores for each criterion for the Acts and Regulations, Codes of Practice and guidance material were calculated (see Table 5). The findings of the gap analysis are shown in Figure 2. It is evident that the softer guidance documents make more reference to psychological health and/or psychosocial risk management in all five criteria in comparison to the legally binding documents. 
Table 1: Policy scorecard: key dimensions and scoring criteria (from Leka et al., 2015)

\begin{tabular}{|c|c|c|c|c|c|c|}
\hline Key dimensions & 0 & 1 & 2 & 3 & 4 & 5 \\
\hline $\begin{array}{l}\text { Psychological } \\
\text { health in the } \\
\text { workplace referred } \\
\text { to in the objectives } \\
\text { and scope of the } \\
\text { policy }\end{array}$ & $\begin{array}{l}\text { Not covered by the general } \\
\text { objectives or scope of the } \\
\text { policy }\end{array}$ & $\begin{array}{l}\text { Covered in } \\
\text { principle but not } \\
\text { effectively } \\
\text { addressed }\end{array}$ & $\begin{array}{l}\text { Only implicitly covered by the } \\
\text { objectives/scope of the } \\
\text { policy }\end{array}$ & $\begin{array}{l}\text { Partially covered by the } \\
\text { objectives/scope of the } \\
\text { policy }\end{array}$ & $\begin{array}{l}\text { Sufficient coverage } \\
\text { but lack of } \\
\text { definitions of key } \\
\text { terms within the } \\
\text { policy }\end{array}$ & $\begin{array}{c}\text { Comprehensively } \\
\text { covered by the general } \\
\text { objective or scope of the } \\
\text { policy }\end{array}$ \\
\hline $\begin{array}{l}\text { Coverage of } \\
\text { exposure factors in } \\
\text { relation to } \\
\text { psychological } \\
\text { health in the } \\
\text { workplace }\end{array}$ & $\begin{array}{l}\text { No reference to or } \\
\text { acknowledgement/coverage } \\
\text { of exposure factors in } \\
\text { relation to mental health in } \\
\text { the workplace }\end{array}$ & $\begin{array}{c}\text { Covered in } \\
\text { principle but not } \\
\text { effectively } \\
\text { addressed }\end{array}$ & $\begin{array}{c}\text { Only implicit } \\
\text { acknowledgement/coverage } \\
\text { of some exposure factors in } \\
\text { relation to psychological } \\
\text { health in the workplace }\end{array}$ & $\begin{array}{c}\text { Partial } \\
\text { acknowledgement/coverage } \\
\text { of exposure factors in } \\
\text { relation to psychological } \\
\text { health in the workplace }\end{array}$ & $\begin{array}{l}\text { Sufficient coverage } \\
\text { but lack of } \\
\text { specificity on } \\
\text { exposure factors in } \\
\text { relation to } \\
\text { psychological health } \\
\text { in the workplace }\end{array}$ & $\begin{array}{c}\text { Comprehensive } \\
\text { coverage of exposure } \\
\text { factors in relation to } \\
\text { psychological health in } \\
\text { the workplace }\end{array}$ \\
\hline $\begin{array}{c}\text { Coverage of } \\
\text { psychological } \\
\text { health } \\
\text { problems/disorders } \\
\text { at work and related } \\
\text { outcomes }\end{array}$ & $\begin{array}{c}\text { No reference or } \\
\text { acknowledgement/coverage } \\
\text { of psychological health } \\
\text { problems/disorders at work } \\
\text { and related outcomes }\end{array}$ & $\begin{array}{c}\text { Covered in } \\
\text { principle but not } \\
\text { effectively } \\
\text { addressed }\end{array}$ & $\begin{array}{c}\text { Only implicit } \\
\text { acknowledgement/coverage } \\
\text { of psychological health } \\
\text { problems/disorders at work } \\
\text { and related outcomes }\end{array}$ & $\begin{array}{c}\text { Partial } \\
\text { acknowledgement/coverage } \\
\text { of psychological health } \\
\text { problems/disorders at work } \\
\text { and related outcomes }\end{array}$ & $\begin{array}{c}\text { Sufficient coverage } \\
\text { but lack of } \\
\text { specificity on } \\
\text { psychological health } \\
\text { problems/disorders } \\
\text { at work and related } \\
\text { outcomes }\end{array}$ & $\begin{array}{c}\text { Comprehensive } \\
\text { coverage of } \\
\text { psychological health } \\
\text { problems/disorders at } \\
\text { work and related } \\
\text { outcomes }\end{array}$ \\
\hline $\begin{array}{l}\text { Coverage of risk } \\
\text { assessment } \\
\text { aspects in relation } \\
\text { to psychological }\end{array}$ & $\begin{array}{c}\text { No reference to or } \\
\text { acknowledgement/coverage } \\
\text { of risk assessment aspects }\end{array}$ & $\begin{array}{c}\text { Covered in } \\
\text { principle but not }\end{array}$ & $\begin{array}{c}\text { Only implicit } \\
\text { acknowledgement/coverage } \\
\text { of risk assessment aspects }\end{array}$ & $\begin{array}{c}\text { Partial } \\
\text { acknowledgement/coverage } \\
\text { of risk assessment aspects }\end{array}$ & $\begin{array}{l}\text { Sufficient coverage } \\
\text { but lack of } \\
\text { specificity on risk } \\
\text { assessment aspects }\end{array}$ & $\begin{array}{c}\text { Comprehensive } \\
\text { coverage of risk } \\
\text { assessment aspects in }\end{array}$ \\
\hline
\end{tabular}




\begin{tabular}{|c|c|c|c|c|c|c|}
\hline $\begin{array}{l}\text { health in the } \\
\text { workplace }\end{array}$ & $\begin{array}{l}\text { in relation to psychological } \\
\text { health in the workplace }\end{array}$ & $\begin{array}{l}\text { effectively } \\
\text { addressed }\end{array}$ & $\begin{array}{l}\text { in relation to psychological } \\
\text { health in the workplace }\end{array}$ & $\begin{array}{l}\text { in relation to psychological } \\
\text { health in the workplace }\end{array}$ & $\begin{array}{c}\text { in relation to } \\
\text { psychological health } \\
\text { in the workplace }\end{array}$ & $\begin{array}{l}\text { relation to psychological } \\
\text { health in the workplace }\end{array}$ \\
\hline $\begin{array}{l}\text { Coverage of } \\
\text { preventive actions } \\
\text { in relation to } \\
\text { psychological } \\
\text { health in the } \\
\text { workplace }\end{array}$ & $\begin{array}{l}\text { No reference to or } \\
\text { acknowledgement/coverage } \\
\text { of preventive actions in } \\
\text { relation to psychological } \\
\text { health in the workplace }\end{array}$ & $\begin{array}{l}\text { Covered in } \\
\text { principle but not } \\
\text { effectively } \\
\text { addressed }\end{array}$ & $\begin{array}{c}\text { Only implicit } \\
\text { acknowledgement/coverage } \\
\text { of preventive actions in } \\
\text { relation to mental health in } \\
\text { the workplace }\end{array}$ & $\begin{array}{c}\text { Partial } \\
\text { acknowledgement/coverage } \\
\text { of preventive actions in } \\
\text { relation to psychological } \\
\text { health in the workplace }\end{array}$ & $\begin{array}{l}\text { Sufficient coverage } \\
\text { but lack of } \\
\text { specificity on } \\
\text { preventive actions } \\
\text { in relation to } \\
\text { psychological health } \\
\text { in the workplace }\end{array}$ & $\begin{array}{l}\text { Comprehensive } \\
\text { coverage of preventive } \\
\text { actions in relation to } \\
\text { psychological health in } \\
\text { the workplace }\end{array}$ \\
\hline
\end{tabular}

Table 2. Policy scores: Acts and Regulations from Each Jurisdiction

\begin{tabular}{|c|c|c|c|c|c|c|c|}
\hline \multirow{2}{*}{$\begin{array}{l}\text { Act and } \\
\text { Regulations }\end{array}$} & \multicolumn{7}{|c|}{ Scores } \\
\hline & $\begin{array}{l}\text { Jurisdiction that } \\
\text { corresponds to the } \\
\text { policy document }\end{array}$ & $\begin{array}{l}\text { Psychological health } \\
\text { in the workplace } \\
\text { referred to in the } \\
\text { objectives/scope of } \\
\text { the policy }\end{array}$ & $\begin{array}{c}\text { Coverage of } \\
\text { exposure factors in } \\
\text { relation to } \\
\text { psychological health } \\
\text { in the workplace }\end{array}$ & $\begin{array}{c}\text { Coverage of } \\
\text { psychological health } \\
\text { problems/disorders at } \\
\text { work and related } \\
\text { outcomes }\end{array}$ & $\begin{array}{l}\text { Coverage of risk } \\
\text { assessment aspects } \\
\text { in relation to } \\
\text { psychological health } \\
\text { in the workplace }\end{array}$ & $\begin{array}{c}\text { Coverage of } \\
\text { preventive actions in } \\
\text { relation to } \\
\text { psychological health } \\
\text { in the workplace }\end{array}$ & $\begin{array}{l}\text { Overall } \\
\text { (max. } \\
25)\end{array}$ \\
\hline $\begin{array}{l}\text { Work Health } \\
\text { and Safety } \\
\text { Model Act } \\
2011\end{array}$ & $\begin{array}{c}\text { South Australia, } \\
\text { Queensland } \\
\text { Tasmania, Northern } \\
\text { Territory, New South } \\
\text { Wales, Australian } \\
\text { Capital Territory }\end{array}$ & 5 & 2 & 1 & 1 & 2 & 11 \\
\hline $\begin{array}{l}\text { Work Health } \\
\text { and Safety } \\
\text { Model }\end{array}$ & $\begin{array}{c}\text { South Australia, } \\
\text { Queensland } \\
\text { Tasmania, Northern } \\
\text { Territory, New South }\end{array}$ & 1 & 1 & 1 & 2 & 2 & 7 \\
\hline
\end{tabular}




\begin{tabular}{|c|c|c|c|c|c|c|c|}
\hline $\begin{array}{l}\text { Regulations } \\
2011\end{array}$ & $\begin{array}{c}\text { Wales, Australian } \\
\text { Capital Territory }\end{array}$ & & & & & & \\
\hline $\begin{array}{c}\text { Occupational } \\
\text { Safety and } \\
\text { Health Act } \\
1984\end{array}$ & Western Australia & 1 & 0 & 0 & 0 & 0 & 1 \\
\hline $\begin{array}{c}\text { Occupational } \\
\text { Safety and } \\
\text { Health } \\
\text { Regulations } \\
1996\end{array}$ & Western Australia & 1 & 0 & 0 & 0 & 0 & 1 \\
\hline $\begin{array}{c}\text { Occupational } \\
\text { Health and } \\
\text { Safety Act } \\
2004\end{array}$ & Victoria & 5 & 2 & 1 & 1 & 2 & 11 \\
\hline $\begin{array}{l}\text { Occupational } \\
\text { Health and } \\
\text { Safety } \\
\text { Regulations } \\
2017\end{array}$ & Victoria & 1 & 1 & 1 & 2 & 2 & 7 \\
\hline $\begin{array}{c}\text { Total } \\
\text { Scores }\end{array}$ & & 14 & 6 & 4 & 6 & 8 & 38 \\
\hline
\end{tabular}


Table 3 Policy Scores: Codes of Practice

\begin{tabular}{|c|c|c|c|c|c|c|}
\hline Code of Practice & & & Sco & & & \\
\hline & $\begin{array}{c}\text { Psychological } \\
\text { health in the } \\
\text { workplace referred } \\
\text { to in the } \\
\text { objectives/scope of } \\
\text { the policy }\end{array}$ & $\begin{array}{l}\text { Coverage of } \\
\text { exposure factors in } \\
\text { relation to } \\
\text { psychological } \\
\text { health in the } \\
\text { workplace }\end{array}$ & $\begin{array}{c}\text { Coverage of } \\
\text { psychological } \\
\text { health } \\
\text { problems/disorders } \\
\text { at work and related } \\
\text { outcomes }\end{array}$ & $\begin{array}{l}\text { Coverage of risk } \\
\text { assessment } \\
\text { aspects in relation } \\
\text { to psychological } \\
\text { health in the } \\
\text { workplace }\end{array}$ & $\begin{array}{l}\text { Coverage of } \\
\text { preventive actions } \\
\text { in relation to } \\
\text { psychological } \\
\text { health in the } \\
\text { workplace }\end{array}$ & $\begin{array}{l}\text { Overall } \\
\text { (max. 25) }\end{array}$ \\
\hline $\begin{array}{l}\text { How to Manage Health } \\
\text { and Safety Risks, } 2011 \\
\text { (SWA) }\end{array}$ & 3 & 3 & 1 & 3 & 3 & 13 \\
\hline $\begin{array}{l}\text { Work Health and Safety } \\
\text { Consultation, Co- } \\
\text { operation and Co- } \\
\text { ordination, } 2011 \\
\text { (SWA) }\end{array}$ & 1 & 3 & 1 & 3 & 3 & 11 \\
\hline $\begin{array}{c}\text { Violence, Aggression \& } \\
\text { Bullying at Work, } 2010 \\
\text { (Western Australia) }\end{array}$ & 5 & 5 & 4 & 4 & 4 & 22 \\
\hline$\frac{\frac{\text { Fatigue Management }}{\text { for Commercial Vehicle }}}{\underline{\text { Drivers, 2004 }}}$ & 4 & 4 & 3 & 3 & 3 & 17 \\
\hline
\end{tabular}




\begin{tabular}{|c|c|c|c|c|c|c|}
\hline $\begin{array}{c}\text { OHS in Call Centres, } \\
2005 \\
\text { (Western Australia) }\end{array}$ & 3 & 4 & 3 & 4 & 4 & 18 \\
\hline $\begin{array}{c}\text { OHS in the Western } \\
\text { Australia Public Sector, } \\
2007 \\
\text { (Western Australia) }\end{array}$ & 2 & 2 & 0 & 2 & 2 & 8 \\
\hline $\begin{array}{l}\text { Working Hours, } 2006 \\
\text { (Western Australia) }\end{array}$ & 3 & 3 & 2 & 4 & 4 & 16 \\
\hline Total Scores & 21 & 24 & 14 & 23 & 23 & 105 \\
\hline
\end{tabular}




\section{Table 4. Policy Scores: Guidance Material}

\section{Guidance Material}

\section{Document}

\begin{tabular}{|c|c|c|c|c|c|c|}
\hline & $\begin{array}{l}\text { Psychological health in } \\
\text { the workplace referred } \\
\text { to in the } \\
\text { objectives/scope of the } \\
\text { policy }\end{array}$ & $\begin{array}{l}\text { Coverage of } \\
\text { exposure factors in } \\
\text { relation to } \\
\text { psychological } \\
\text { health in the } \\
\text { workplace }\end{array}$ & $\begin{array}{c}\text { Coverage of } \\
\text { psychological health } \\
\text { problems/disorders at } \\
\text { work and related } \\
\text { outcomes }\end{array}$ & $\begin{array}{l}\text { Coverage of risk } \\
\text { assessment aspects } \\
\text { in relation to } \\
\text { psychological health } \\
\text { in the workplace }\end{array}$ & $\begin{array}{l}\text { Coverage of } \\
\text { preventive actions } \\
\text { in relation to } \\
\text { psychological health } \\
\text { in the workplace }\end{array}$ & $\begin{array}{l}\text { Over } \\
\text { all } \\
\text { (max. } \\
25)\end{array}$ \\
\hline $\begin{array}{l}\text { Guide for Preventing } \\
\text { and Responding to } \\
\text { Workplace Bullying, } \\
2016 \\
\text { (SWA) }\end{array}$ & 5 & 4 & 4 & 3 & 5 & 21 \\
\hline $\begin{array}{c}\text { Dealing with } \\
\text { Workplace Bullying - A } \\
\text { Worker's Guide, } 2016 \\
\text { (SWA) }\end{array}$ & 5 & 1 & 3 & 0 & 0 & 9 \\
\hline $\begin{array}{l}\text { Guide for Managing } \\
\text { the Risk of Fatigue at } \\
\text { Work, } 2013 \\
\text { (SWA) }\end{array}$ & 5 & 5 & 4 & 4 & 5 & 23 \\
\hline $\begin{array}{c}\text { Fatigue Management - } \\
\text { a Workers' Guide, } \\
2013 \\
\text { (SWA) }\end{array}$ & 3 & 2 & 2 & 0 & 3 & 10 \\
\hline
\end{tabular}

Scores 


\begin{tabular}{|c|c|c|c|c|c|c|}
\hline $\begin{array}{c}\frac{\text { Preventing }}{\text { Psychological Injury }} \\
\frac{\text { Under Work Health \& }}{\frac{\text { Safety Laws (Fact }}{\text { Sheet), 2014 }}} \\
\text { (SWA) }\end{array}$ & 5 & 5 & 2 & 4 & 4 & 20 \\
\hline $\begin{array}{c}\text { Workers' } \\
\text { Compensation } \\
\text { Legislation \& } \\
\text { Psychological Injury } \\
\text { Factsheet, 2014 } \\
\text { (SWA) }\end{array}$ & 5 & 1 & 4 & 0 & 0 & 10 \\
\hline $\begin{array}{c}\text { The Principles of Good } \\
\text { Work Design } \\
\text { Handbook, } 2015 \\
\text { (SWA) }\end{array}$ & 3 & 4 & 1 & 2 & 4 & 14 \\
\hline $\begin{array}{c}\text { Worker Representation } \\
\text { and Participation } \\
\text { Guide, 2016 } \\
\text { (SWA) }\end{array}$ & 1 & 0 & 0 & 0 & 0 & 1 \\
\hline $\begin{array}{l}\text { Preventing and } \\
\text { Managing Work- } \\
\text { related Stress, } 2017 \\
\text { (Victoria) }\end{array}$ & 5 & 5 & 3 & 4 & 4 & 21 \\
\hline $\begin{array}{c}\frac{\text { Fatigue Prevention in }}{\text { the Workplace, } 2017} \\
\text { (Victoria) }\end{array}$ & 4 & 5 & 3 & 5 & 5 & 22 \\
\hline$\frac{\text { Fatigue Management }}{\frac{\text { for the Forestry }}{\text { Industry, 2004 }}}$ & 4 & 3 & 2 & 4 & 5 & 18 \\
\hline
\end{tabular}




\begin{tabular}{|c|c|c|c|c|c|c|}
\hline $\begin{array}{l}\frac{\text { Preventing Work- }}{\text { related Stress - }} \\
\text { Examples of Risk } \\
\frac{\text { Control Measures, }}{\text { Date Unknown }} \\
\text { (Victoria) }\end{array}$ & 5 & 5 & 1 & 1 & 5 & 17 \\
\hline$\frac{\text { Workplace Bullying - }}{\frac{\text { Prevention and }}{\text { Response, 2012 }}}$ & 1 & 1 & 1 & 1 & 3 & 7 \\
\hline 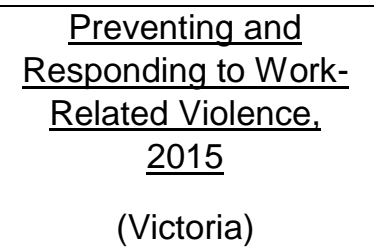 & 5 & 4 & 1 & 5 & 5 & 20 \\
\hline$\frac{\text { More information about }}{\frac{\text { occupational violence }}{\text { (Victoria) }}}$ & 1 & 4 & 1 & 4 & 4 & 14 \\
\hline$\frac{\frac{\text { Prevention and }}{\text { Management of }}}{\frac{\text { Aggression in Health }}{\text { Services, } 2017}}$ & 4 & 4 & 2 & 5 & 5 & 20 \\
\hline $\begin{array}{l}\frac{\text { Guide for Workers - }}{\text { Consultation, }} \\
\text { Representation and }\end{array}$ & 3 & 1 & 0 & 1 & 2 & 7 \\
\hline
\end{tabular}




\begin{tabular}{|c|c|c|c|c|c|c|}
\hline 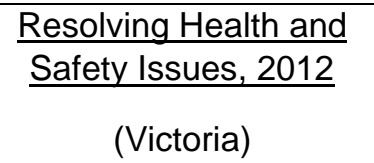 & & & & & & \\
\hline $\begin{array}{l}\frac{\text { Guide for Victorian }}{\text { Workplaces - }} \\
\frac{\text { Consultation, } 2017}{\text { (Victoria) }}\end{array}$ & 1 & 1 & 0 & 1 & 2 & 5 \\
\hline $\begin{array}{c}\frac{\text { More Information }}{\text { about Consultation }} \\
\frac{\text { with Health and Safety }}{\text { Representatives, } 2012} \\
\text { (Victoria) }\end{array}$ & 1 & 0 & 0 & 2 & 2 & 5 \\
\hline $\begin{array}{c}\frac{\text { Alcohol in the }}{\text { Workplace - }} \\
\frac{\text { Guidelines for }}{\text { Developing a }} \\
\frac{\text { Workplace Alcohol }}{\frac{\text { Policy, 2017 }}{\text { (Victoria) }}}\end{array}$ & 3 & 4 & 4 & 3 & 5 & 19 \\
\hline $\begin{array}{l}\text { Supporting Good } \\
\text { Mental Health in the } \\
\text { Workplace, } 2014 \\
\text { (Western Australia) }\end{array}$ & 5 & 1 & 4 & 1 & 3 & 14 \\
\hline $\begin{array}{c}\text { Psychologically Safe } \\
\text { and Healthy } \\
\text { Workplaces: Risk } \\
\text { Management } \\
\text { Approach Toolkit, } 2014\end{array}$ & 5 & 5 & 5 & 5 & 4 & 24 \\
\hline
\end{tabular}




\begin{tabular}{|c|c|c|c|c|c|c|}
\hline (Western Australia) & & & & & & \\
\hline $\begin{array}{c}\text { Stresswise - } \\
\text { Preventing Work- } \\
\text { Related Stress, } 2007 \\
\text { (Victoria) }\end{array}$ & 5 & 4 & 4 & 5 & 4 & 22 \\
\hline $\begin{array}{c}\text { Positive and } \\
\text { Productive Workplace } \\
\text { Guide, } 2016 \\
\text { (New South Wales, } \\
\text { Public Service } \\
\text { Commission) }\end{array}$ & 4 & 3 & 2 & 3 & 4 & 16 \\
\hline $\begin{array}{l}\text { Workers with Mental } \\
\text { Illness a Practical } \\
\text { Guide for Managers, } \\
2010 \text { (Australian } \\
\text { Human Rights } \\
\text { Commission) }\end{array}$ & 5 & 4 & 5 & 4 & 4 & 22 \\
\hline $\begin{array}{c}\text { Comcare Working Well } \\
\text { Together Guide - } \\
\text { Preventing } \\
\text { Psychological Injury }\end{array}$ & 5 & 4 & 2 & 3 & 4 & 18 \\
\hline Total Scores & 98 & 80 & 60 & 70 & 91 & 399 \\
\hline
\end{tabular}




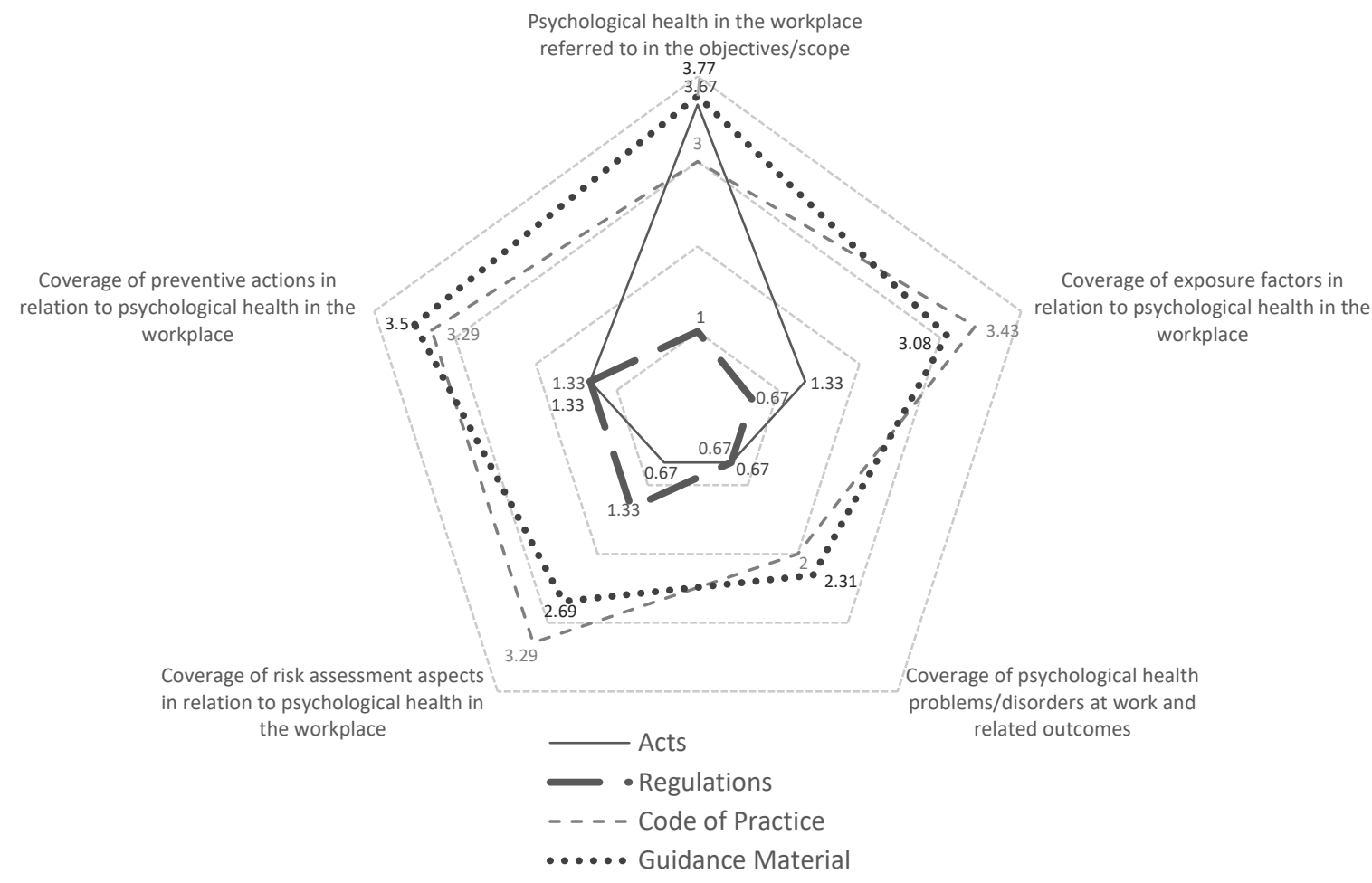

Figure 2. Gap analysis on the coverage of psychosocial risk management criteria across Acts, Regulations, Codes of Practice and guidance material

Table 5. Average scores of Policy Documents

\begin{tabular}{|c|c|c|c|c|c|c|}
\hline & $\begin{array}{l}\text { Psychological } \\
\text { health in the } \\
\text { workplace } \\
\text { referred to in the } \\
\text { objectives/scope } \\
\text { of the policy }\end{array}$ & $\begin{array}{l}\text { Coverage of } \\
\text { exposure } \\
\text { factors in } \\
\text { relation to } \\
\text { psychological } \\
\text { health in the } \\
\text { workplace }\end{array}$ & $\begin{array}{l}\text { Coverage of } \\
\text { psychological } \\
\text { health } \\
\text { problem/disorders } \\
\text { at work and } \\
\text { related outcomes }\end{array}$ & $\begin{array}{l}\text { Coverage of } \\
\text { risk } \\
\text { assessment } \\
\text { aspects in } \\
\text { relation to } \\
\text { psychological } \\
\text { health in the } \\
\text { workplace }\end{array}$ & $\begin{array}{l}\text { Coverage of } \\
\text { preventive } \\
\text { actions in } \\
\text { relation to } \\
\text { psychological } \\
\text { health in the } \\
\text { workplace }\end{array}$ & $\begin{array}{l}\text { Total } \\
\text { Score }\end{array}$ \\
\hline Acts & 3.67 & 1.33 & .67 & .67 & 1.33 & 7.67 \\
\hline Regulations & 1 & .67 & .67 & 1.33 & 1.33 & 5 \\
\hline $\begin{array}{l}\text { Codes of } \\
\text { Practice }\end{array}$ & 3 & 3.43 & 2 & 3.29 & 3.29 & 15.01 \\
\hline
\end{tabular}




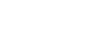

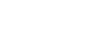


We identified several other documents within the literature that mentioned psychosocial hazards within a particular context. However, these documents were not scored in the review as they 1) only stated or mentioned the terms 'psychosocial risk' or 'psychological health' and 2) were not stated by participants as being used to regulate. These documents include: 1) the 'Managing the Work Environment and Facilities Code of Practice', which mentions psychosocial hazards in the context of remote and isolated work, 2) Hazardous Manual Tasks Code of Practice that includes several psychosocial hazards in its analysis of risk for musculoskeletal disorders, and 3) Manual Handling which includes psychosocial hazards in the review of risk control measures. It should also be acknowledged there are provisions in the Northern Territory, South Australian and Victorian Regulations that relate specifically to the mining industry and include mention of psychosocial hazards or risks. The majority of these mining Regulations include reference to fatigue and psychological impairment. Within New South Wales and South Australia there is also an obligation for mine operators to manage risks of health and safety that are related to fatigue, alcohol and drug use. The remaining four jurisdictions have separate mining regulations.

\section{Discussion}

The aim of this study was to review WHS policy documents relevant to the protection and promotion of psychological health in Australian workplaces. Analysis of the documents was conducted to identify the strengths and gaps of both regulatory and non-regulatory policies. Our review revealed a total of 39 available WHS policy documents that focused on protecting and promoting work-related psychological health or managing psychosocial hazards. Six of these policy documents are regulatory, so legally enforceable (i.e. hard law) - and 33 are not legally binding (i.e. voluntary). Overall, the regulatory policies received lower scores (Acts $=7.67$, Regulations $=5$ ) than the non-regulatory policies (Codes of Practice $=15.01$, Guidance 
Material $=15.35)($ consistent with Leka et al.'s (2015) findings). However, within each layer of the policy framework (see Figure 2) there is high variation in scores and across each criterion as presented in Tables 2, 3 and 4 .

First, it should be acknowledged that whilst some policy documents received low scores for specific criteria this does not imply that the policy document is insufficient overall. Rather, the document may adopt a different focus (e.g. consultation, co-operation and co-ordination practices) or still have valuable information in a broader context. Second, it must be stated that each layer of the regulatory instruments presents a different purpose. For instance, the Acts are intended to be more outcome focused and so do not provide detail on how to comply with the outlined obligations. Regulations provide further detail on the features of compliance, and are more specific about discrete hazards and administrative arrangements, about how the outcomes (from the Act) are to be achieved. Codes and Guidance are intended to provide detail on how to comply with the requirements of the Acts and Regulations and so include much more specific detail, and may even be industry specific in nature. Therefore, in light of the outcome focus of the legislative framework (through specifying duties and processes), it would be impractical to expect a high level of practical detail within the Acts and Regulation documents, which must be generic enough to apply to all workplaces. It is therefore logical that the soft law policies have greater scope to include more principles relating to managing psychosocial hazards and promoting psychological health. However, this logic does not undermine the fact that attention should be given to psychological health with respect to terms and other psychosocial risk management principles (e.g. specific mention of potential exposure factors) within higher level regulatory documents. This fact is well-supported within the literature and also by the growing evidence of poor work-related health in Australia.

In relation to the three identified Acts, these documents scored poorly across criteria (ranging from .67 to 1.33), with exception to 'psychological health outlined in the scope of the 
policy' (3.67), indicating partial coverage of these criteria. Therefore, most criteria (e.g. preventive actions) are only covered in principle in the Act, and lack sufficient or comprehensive coverage. The harmonised WHS Act 2011 (adopted across most jurisdictions), and the Occupational Health and Safety Act 1984 in Victoria, scored highest across the criteria. In particular, both Acts scored a 5 for outlining psychological health within the policy scope/objective. Western Australia's Act -the Occupational Health and Safety Act, 2004 scored poorest (1) for not including any reference to psychological health. It is clear that greater national consistency amongst legislation is needed, supporting recent findings by Potter et al. (2017), which used the PSC framework to evaluate a policy change across jurisdictions. Results showed a significant difference over time for jurisdictions that standardised their policy approaches to the Model legislation, which specifies health to include psychological health. Victoria was not included in this study due to lack of longitudinal data. Western Australia did not adopt the policy change and showed a downward trend in PSC levels over time. Despite this, their PSC levels remained high in comparison to other jurisdictions. Whilst the reasons for this requires further exploration, this jurisdiction has produced specific Codes of Practice which reflect targeted work on addressing psychosocial hazards, which may be a contributing factor to higher PSC.

In regard to the six Regulation policy documents, these received low average scores consistently across all criteria (ranging from .67 to 1.33). The Acts scored higher, or the same, in comparison to the Regulations across all criteria except for the risk assessment, in which the Regulations scored slightly higher. Scores for the Regulations show that all criteria are only covered in principle at the most. A contributing factor to these low scores is that within these policy documents, there is no mention of psychosocial factors or psychological health. These findings align with previous research by Johnstone et al. (2011) and Bluff (2016), stating that there are only broad obligations within the legislation. As such, there is a case for reviewing the 
Regulations across all jurisdictions to specifically reference psychological health or psychosocial hazards. Overall, the current Acts and Regulations do not include psychosocial risk management principles, with poor coverage of exposure factors, psychological health problems and related outcomes, risks assessment and preventive action.

Further, our review identified 7 Codes of Practice and these received scores that were higher than both the Acts and Regulations (average scores ranging from 2 to 3.43). Only two of these codes were created as part of the harmonised legislation, and were general in terms of managing risks and WHS consultation, cooperation and coordination. The remaining Codes of Practice were developed by Western Australia and are focussed on specific issues including fatigue, violence, aggression and bullying and working hours. It is interesting that the central focus of the Codes is on these three issues as it demonstrates whether there is high consensus among policy makers. As well, the documents are concentrated on the public sector, call centres and drivers. However, other psychosocial hazards or industries are not covered within this level of the policy framework, which could be a point for future improvement. With respect to the scoring criteria, the Codes of Practice rated highest for coverage of exposure factors (3.43), risk assessment (3.29) and preventive actions (3.29), with all scores above 3, indicating partial to sufficient coverage. Codes of Practice also scored 3 for having psychological health referred in the objective or scope, indicating partial acknowledgment or coverage. The coverage of psychological health problems/disorders and related outcomes was only covered implicitly within these documents and is an area that should be improved.

In addition, the review identified 26 guidance policy documents intended to help workplaces in meeting obligations, representing the highest proportion of documents. In general, the guidance material available is more focused on specific hazards and therefore uses more detailed terminology relevant to psychosocial hazards. For instance, in comparison to more generally discussing WHS risks or outlining broad duties, there is focused guidance on 
issues such as bullying, which is tailored to inform both employers and employees what constitutes bullying and what to do if it arises at work. According to our review, the majority of guidance material has been developed by the state of Victoria. In the study by Potter et al. (2017) it was found that Victoria scored the second highest PSC scores in Australia. Therefore, this level of activity in producing guidance for organisations may be having a positive effect on the PSC of the jurisdiction. Overall, this review revealed the guidance material scored higher than the regulatory documents and the Codes of Practice, with average scores ranging from 2.31 to 3.77. The highest scoring criterion was the inclusion of psychological health in the scope and objective (3.77), coverage of preventive actions (3.50) and coverage of exposure factors (3.08). The coverage of psychological health problems or disorders and outcomes and risk assessment received scores 2.31 and 2.69 respectively, suggesting implicit coverage and an area for potential improvement. However, within the pool of identified guidance material, there is a high degree of variation and many individual documents sufficiently covered all criteria in their own right (refer to Table 4). Ten of these documents scored over twenty, which was stated in Leka et al. (2015) as suggesting that these policy initiatives covered many aspects of psychosocial risk management criteria. Respondents also revealed that they refer to international polices in their roles to guide organisations with managing psychosocial hazards. In particular the implementation Guide for the Canadian Standard (Canadian Standards Association, 2013) and the PRIMA-EF framework (WHO, 2008) were emphasised as significant resources for regulators. The fact that Australian regulators need to refer to international guides and literature, further suggests that the current legislation or Australian guidance material may not be adequate for the practical management of psychological health and psychosocial hazards.

Total average scores showed that overall the Regulations scored poorest (5), then the Acts (7.67), Codes of Practice (15.01) and guidance material (15.35). From the gap analysis it 
is evident that many criteria could be strengthened within both the regulatory and nonregulatory documents. Considering the WHS policy framework and documents in their entirety, neither the regulatory nor non-regulatory documents scored above an average of 3.77. As a score of 3 represents only partial coverage in respect to the scoring criteria, it is of concern that not one collective type of policy provided sufficient coverage of these aspects overall. Therefore, it is recommended that policy-makers improve the legally binding Act and Regulations to encompass a stronger focus on psychological health and embed core principles of psychosocial risk management. These results are consistent with findings by Leka et al. (2015) (with the exception of psychological health being referred to in the objectives scope of the policy) in which no binding policy received a score higher than 2.5. However, in Leka et al.'s review (2015) several voluntary policies attained scores of 4.5, which is higher than the current reviews' highest score of 3.77. Yet, it should be noted that subsequent to this review paper being conducted, SWA developed and released a guide to assist workplaces meet their duties for work-related psychological health and safety (SWA, 2018c). This guide reflects positive movement towards psychosocial risk management being enacted in Australian organisations.

\section{Policy and Practical Implications}

Whilst it is acknowledged that the function of the Act and Regulations is to focus on broad outcomes (given they are the highest structural point of the legislation) this does not detract from the fact that terminology should be included and further broad principles relating to psychosocial risk management should be extended. As well, across both the regulatory and non-regulatory documents, the coverage of psychological health problems or disorders and related outcomes scored lowest, highlighting strong need for improvement. Inclusion of specific psychological health issues and work-related outcomes is likely to persuade employers 
of the significance of psychosocial hazards and their profound influence on health and safety outcomes, as well as motivating better psychosocial risk management. In addition, risk assessment was only partially included within Codes of Practice. Yet, given the risk management focus of the Australian WHS legislation, risk assessment should be strengthened in the Acts and the Regulations where it is only covered in principle. In particular, risk assessment and management would be best placed in the Regulations, since the document already outlines a process of identifying, assessing and controlling risks to health through a hierarchy of control. Therefore adding more specification to this section would make it clear to inspectors and businesses that psychosocial risks are of equal importance to physical risks.

In general, most forms of policy documents showed strong inclusion of psychological health in the objective of the policy (except the Regulations). Nevertheless it is apparent that greater emphasis should be placed on risk assessment, preventive action and including psychological health outcomes in the policies. Non-regulatory polices showed good coverage of exposure factors and preventive action. We argue that a more evident legislative focus on the assessment and prevention of risks would push employers to monitor their employees' health and motivate a swifter response if high risk of harm was detected. Additionally, a greater focus on psychosocial risk management in the WHS laws would give inspectors more scope to ensure risk assessment protocols are in place within organisations and that efforts are conducted to ensure work is designed properly to prevent psychological harm. This is supported with findings from a recent international comprehensive review on the inspection and prevention of psychosocial hazards at work, which highlighted the extreme difficulties and global inconsistencies surrounding policies, standards and regulation in relation to psychosocial risk management (Weissbrodt \& Giauque, 2017). The review found extensive support for better regulation of psychosocial hazards, with the biggest concern around being able to inspect and enforce change. 
The need for greater Australian legislative clarity echoes a previous call made in Germany, whereby until 2013, there was no specific inclusion of "psychological stress" or "psychosocial risks" in the Safety and Health at Work Act. This presented as an issue as data from the National Labour Force survey revealed that only $22 \%$ of German organisations reported conducting risk assessments on work-related stress or psychosocial risk factors (Lohmann-Haislah, 2012). In light of these findings, and following the necessary political discourse, the Occupational Safety and Health Act was changed in 2013 to explicitly state organisations should conduct psychosocial risk assessments and that follow up measures should focus on both physical and psychological health (Lohmann-Haislah, 2012). Such constructive change could also be implemented within Australian WHS laws.

\section{Limitations}

There are several limitations within this study. While every attempt was made to reduce subjectivity and increase inter-rater reliability, the scoring of the policies was inevitably a subjective process. While we conducted a review of the Australian legislation and documents, we did not request information from all jurisdictions. The remaining jurisdictions have the same legislation and policy documents as New South Wales and South Australia, who adopted the Model legislation. Also, while this review provides an overview of the content of Australian policy instruments, it does not draw any conclusions on the uptake and impact of these policies in practice. Rather, the review shows the range of what polices are available and their coverage of psychosocial risk management principles.

In addition, whilst we sought the best informants to assist with identifying policy documents, we observed some limitations in their knowledge. For instance, in one policy template response, the participant(s) had incorrectly listed codes of practice documents under guidance material. Therefore, their knowledge of documents relevant to psychological health 
may not be at a consistently high level. Despite this, we also undertook a comprehensive review of all online regulator sites for each jurisdiction to review all relevant policy documents.

To analyse the policies we used policy scorecard criteria from a previously published study (Leka et al, 2015). However, future research should be conducted to further assess the validity of these criteria. One approach to determine validity is to use the policy scorecard to assess the application of policies in organisations and then to assess the relationship with objective outcomes such as reported psychological injury. Alternatively, determining validity could also be conducted through using these criteria to assess state-level policies over time and their relationship with outcomes from additional data sets such as the AWB project (Dollard \& Bailey, 2014).

\section{Conclusion}

Regulatory WHS policy frameworks represent the cornerstone in setting standards for organisational engagement and compliance in protecting employees' psychological health. The current study provides an overview and gap analysis of the current regulatory and nonregulatory policy documents relating to psychological health (and psychosocial hazards and risks) in Australia. We found that the regulatory policy documents scored lower than nonregulatory documents, suggesting that regulatory policy could be strengthened by incorporating greater psychosocial risk management principles to improve psychological health outcomes. In addition both regulatory and non-regulatory documents could be further improved, by including greater coverage of psychological health problems or disorders and related outcomes. Overall, strategising the protection of work-related psychological health must remain a high priority on the agenda of governments, researchers, unions and policy makers, supported by high levels of organisational education and awareness raising. Future research should seek to understand both the effectiveness and implementation of these policies in greater detail. It would be of 
particular benefit to examine the perspectives of enterprise-based stakeholders, who have the primary role to apply policy within organisations, as well as WHS regulators.

\section{References}

Australian Bureau of Statistics (ABS) 2010. Work-related injuries 2009-10, ABS cat no 63224.0. Canberra, Australia: Australian Bureau of Statistics.

Bailey,T., Dollard, M.F., McLinton, S., \& Richards, P. (2015). Psychosocial safety climate, psychosocial and physical factors in the aetiology of musculoskeletal disorder symptoms and workplace injury compensation claims. Work \& Stress, 29(2), 190-211. DOI: $10.1080 / 02678373.2015 .1031855$.

Becher, H., \& Dollard, M. F. (2016). Psychosocial and better productivity in Australian workplaces; Costs, productivity, presenteeism, absenteeism. Canberra, Australia: Safe Work Australia.

Beyondblue. (2014). State of Workplace Mental Health in Australia. NSW, Australia: Beyondblue

Bluff, E. \& Gunningham, N. (2012). Harmonising work health and safety regimes. Australian Journal of Labour Law, 25(2), 85-106.

Bluff, E. (2016). The Regulation and Governance of Psychosocial Risks and Work: A Comparative Analysis across Countries. Part 3 Society, Safety and Health. In Global Collaborative Research 2016: Financial Regulation/Society, Safety \& Health/Trade \& Investment. Korea, Korea Legislation Research Institute.

Bluff, E., Johnstone, R., McNamara, M., \& Quinlan, M. (2012). Enforcing upstream: Australian health and safety inspectors and upstream duty holders. Australian Journal of Labour Law, 25(1), 23-42.

Canadian Standards Association. (2013). Psychological health and safety in the workplace. Prevention, promotion, and guidance to staged implementation, CAN/CSA-Z100313/BNQ 9700-803/2013. Canada, Ottawa: Canadian Standards Association.

Cocker, F., Sanderson, K., \& LaMontagne, A. D. (2017). Estimating the Economic Benefits of Eliminating Job Strain as a Risk Factor for Depression. Journal of occupational and environmental medicine, 59(1), 12-17. DOI: 10.1097/JOM.0000000000000908. 
Cox, T., \& Griffiths, A. (1996). The assessment of psychosocial hazards at work. In M.J. Schabracq, J.A.M. Winnubst, \& C.L. Cooper (Eds.), Handbook of work and health psychology (pp. 127146). Chichester: Wiley.

Cox, T., Griffiths, A., \& Rial-Gonzalez, E. (2000). Research on Work Related Stress. European Agency for Safety and Health at Work. Luxembourg: Office for Official Publications of the European Communities.

Crimes Act. (1958). S62B.

Dollard, M., Bailey, T., McLinton, S., Richards, P., McTernan, W., Taylor, A., \& Bond, S. (2012). The Australian workplace barometer: Report on psychosocial safety climate and worker health in Australia. Canberra, Australia: Safe Work Australia.

Dollard, M.F. \& Bailey, T.S. (2014).The Australian Workplace Barometer: psychosocial safety climate and working conditions in Australia. Australia: Australian Academic Press Group Pty. Ltd, Samford Valley, Queensland.

European Agency for Safety and Health at Work (EU-OSHA, 2012). Drivers and barriers for psychosocial risk management: An analysis of findings of the European survey of enterprises on new and emerging risks (ESENER). Luxembourg City: Publications Office of the European Union.

European Agency for Safety and Health at Work (EU-OSHA, 2017). Second European Survey of Enterprises on New and Emerging Risks (ESENER-2) Overview Report: Managing Safety and Health at Work European Risk Observatory. EU-OSHA.

Fair Work Act 2009 (Cwlth) s789FD

Gunningham, N \& Bluff, E. (2009). What determines efficacy? The roles of codes and guidance materials in occupational safety and health regulation. Policy and Practice in Health and Safety, 7(2), 3-29. DOI: 10.1080/14774003.2009.11667732

Gunningham, N. \& Bluff, E. (2008). Review of key characteristics that determine the efficacy of OHS instruments. Canberra, Australia: Australian Safety and Compensation Council.

Hall, G.B., Dollard, M.F., Tuckey, M.R., Winefield, A.H. \& Thompson, B. (2010). Job demands, work-family conflict, and emotional exhaustion in police officers: A longitudinal test of competing theories, Journal of Occupational \& Organisational Psychology, 83(1), 237-250. DOI: 10.1348/096317908X401723. 
Heads up. (2017) Retrieved from: https://www.headsup.org.au/

Health and Safety Professionals Alliance (HaSPA). (2012). The Core Body of knowledge for Generalist OHS Professionals. Tullamarine, VIC: Safety Institute of Australia.

Jespersen, A. H., Hasle, P., \& Nielsen, K. T. (2016). The wicked character of psychosocial risks: implications for regulation. Nordic Journal of Working Life Studies, 6(3), 23.

Johnstone, R. (2008). Harmonising occupational health and safety regulation in Australia: The first report of the national OHS review. Journal of Applied Law and Policy, 35-58.

Johnstone, R., Quinlan, M., \& McNamara, M. (2011). OHS inspectors and psychosocial risk factors: Evidence from Australia. Safety Science, 49(4), 547-557.DOI: https://doi.org/10.1016/j.ssci.2010.09.016

Leka, S. \& Jain, A. (2014). Policy approaches to occupational and organizational health, In. Bauer, G. F., \& Hämmig, O. (eds), Bridging Occupational, Organizational and Public health: a Transdisciplinary Approach (pp. 231-24). Springer.

Leka, S., Jain, A., Iavicoli, S., \& Di Tecco, C. (2015). An evaluation of the policy context on psychosocial risks and mental health in the workplace in the European Union: achievements, challenges, and the future. BioMed research international, 2015. DOI: http://dx.doi.org/10.1155/2015/213089.

Leka, S., Jain, A., Iavicoli, S., Vartia, M., \& Ertel, M. (2011).The role of policy for the management of psychosocial risks at the workplace in the European Union, Safety Science. 49(4), 558-564. DOI: https://doi.org/10.1016/j.ssci.2010.02.002.

Leka, S., Jain, A., Zwetsloot, G., Vartia, M. \& Pahkin, K., 2008. Psychosocial risk management: The importance and impact of policy level interventions. In: LEKA, S and \& COX, T., eds., The European framework for psychosocial risk management: PRIMA-EF. Nottingham, United Kingdom: I-WHO Publications.

Li, J., Dollard, M. F., Loerbroks, A., \& Angerer, P. (2015). Cardiovascular disease is associated with the perception of worsening psychosocial work characteristics. International journal of cardiology, 186, 149-151. DOI: http://dx.doi.org/10.1016/j.ijcard.2015.03.222.

Lippel, K., Vézina, M., \& Cox, R. (2011). Protection of workers' mental health in Québec: Do general duty clauses allow labour inspectors to do their job?. Safety Science, 49(4), 582-590. 
Lohmann-Haislah, A. (2012). Stressreport Deutschland 2012, psychische anforderungen, ressourcen und befinden. Berlin, Germany: Bundesanstalt für Arbeitsschutz und Arbeitsmedizin

McTernan, W. P., Dollard, M. F., \& LaMontagne, A. D. (2013). Depression in the workplace: An economic cost analysis of depression-related productivity loss attributable to job strain and bullying. Work \& Stress, 27, 321-338.

McTernan, W., Dollard, M. F., \& LaMontagne, A. D. (2014). Estimating lost productivity costs from poor psychological health in the workplace. In M. F. Dollard, and T. S. Bailey. (Eds.), Australian Workplace Barometer: Psychosocial Safety Climate and working conditions in Australia (pp. 239-252). Samford Valley QLD: Australian Academic Press.

National Mental Health Commission (2014). Mentally Healthy Workplace Alliance. Retrieved from: $\quad$ http://www.mentalhealthcommission.gov.au/our-work/mentally-healthyworkplace-alliance.aspx

National Mental Health Commission (2014). Retrieved from: http://www.mentalhealthcommission.gov.au/our-work/mentally-healthy-workplacealliance.aspx

OECD. (2015). Mental Health and Work: Australia, Mental Health and Work: Assessment and Recommendations. Paris, France: OECD Publishing.

Potter, R.E., Dollard, M.F., \& Tuckey, M.R. (2016). Bullying and harassment in Australian workplaces: results from the Australian Workplace Barometer project 2014/2015. Canberra, Australia: Safe Work Australia.

Potter, R.E., Dollard, M.F., Owen, M.S., O’Keeffe, V., Bailey, T.S., \& Leka,S. (2017). Assessing a work health and safety policy intervention using the psychosocial safety climate framework. Safety Science, 100, 91-102. DOI: 10.1016/j.ssci.2017.05.011.

PwC. (2014). Creating a mentally healthy workplace: return on investment analysis. Australia: beyondblue. Australian Government Mental Health Commission, the Mentally Healthy Workplace Alliance.

Quinlan, M. (2007). Organisational restructuring/downsizing, OHS regulation and worker health and wellbeing. International journal of law and psychiatry, 30(4), 385-399. 
Quinlan, M., Johnstone, R., \& McNamara, M. (2009). Australian health and safety inspectors' perceptions and actions in relation to changed work arrangements. Journal of Industrial Relations, 51(4), 557-573. DOI:10.1177/0022185609339519.

Sadłowska-Wrzesińska, J. (2014). Analysis of psychosocial risk in the context of the objectives of macroergonomics. In P. Vink (Ed.), Advances in Social and Organizational Factors, 277e285. Krakov: AHFE Conference.

Safe Work Australia (2010). How to Manage Work Health and Safety Risks Codes of Practice. Canberra, Australia: Safe Work Australia.

$\underline{\text { Safe Work Australia (2012a). Australian Work Health and Safety Strategy 2012-2022. }}$

Retrieved from:

https://www.safeworkaustralia.gov.au/system/files/documents/1702/australian-whsstrategy-2012-2022.pdf

Safe Work Australia. (2012b). Guide to the Work Health and Safety Act. Retrieved from: http://www.safeworkaustralia.gov.au/sites/SWA/about/Publications/Documents/717/ Guide-to-the-WHS-Act.pdf

Safe Work Australia. (2015). Work-related mental disorders profile. Canberra, Australia: Safe Work Australia.

Safe Work Australia. (2015). Work-related mental disorders profile. Canberra, Australia: Safe Work Australia.

Safe Work Australia. (2018). Work-related psychological health and safety: A systematic approach to meeting your duties. Canberra, Australia: Safe Work Australia.

Safe Work. (2013). The incidence of accepted workers' compensation claims for mental stress in Australia. Canberra, Australia: Safe Work Australia.

Schofield, T., Reeve, B., \& McCallum, R. (2014). Australian workplace health and safety regulatory approaches to prosecution: Hegemonising compliance. Journal of Industrial Relations, 56(5), 709-729. DOI: 10.1177/0022185613509625.

Stewart, A., 2013. Stewart's Guide to Employment Law. NSW, Australia: The Federation Press.

Weissbrodt, R., \& Giauque, D. (2017). Labour inspections and the prevention of psychosocial risks at work: A realist synthesis. Safety Science, 14(1), 110-124. DOI: $\underline{10.1016 / j . s s c i .2017 .02 .012}$ 
World Health Organization (2018). Mental health: a state of well-being. Retrieved from: http://www.who.int/features/factfiles/mental_health/en/

World Health Organization. (2008). PRIMA-EF: guidance on the European framework for psychosocial risk management: a resource for employer and worker representatives. Protecting Workers' Health Series No. 9. Geneva, Switzerland: World Health Organization.

Zadow, A. \& Dollard, M.F. (2015), Psychosocial Safety Climate, in S Clarke et al. (eds), The Wiley Blackwell Handbook of the Psychology of Occupational Safety and Workplace. UK: Wiley-Blackwell. 